\title{
EFFECTS OF MANAGEMENT PRACTICES ON GRASSLAND BIRDS: \\ HORNED LARK
}

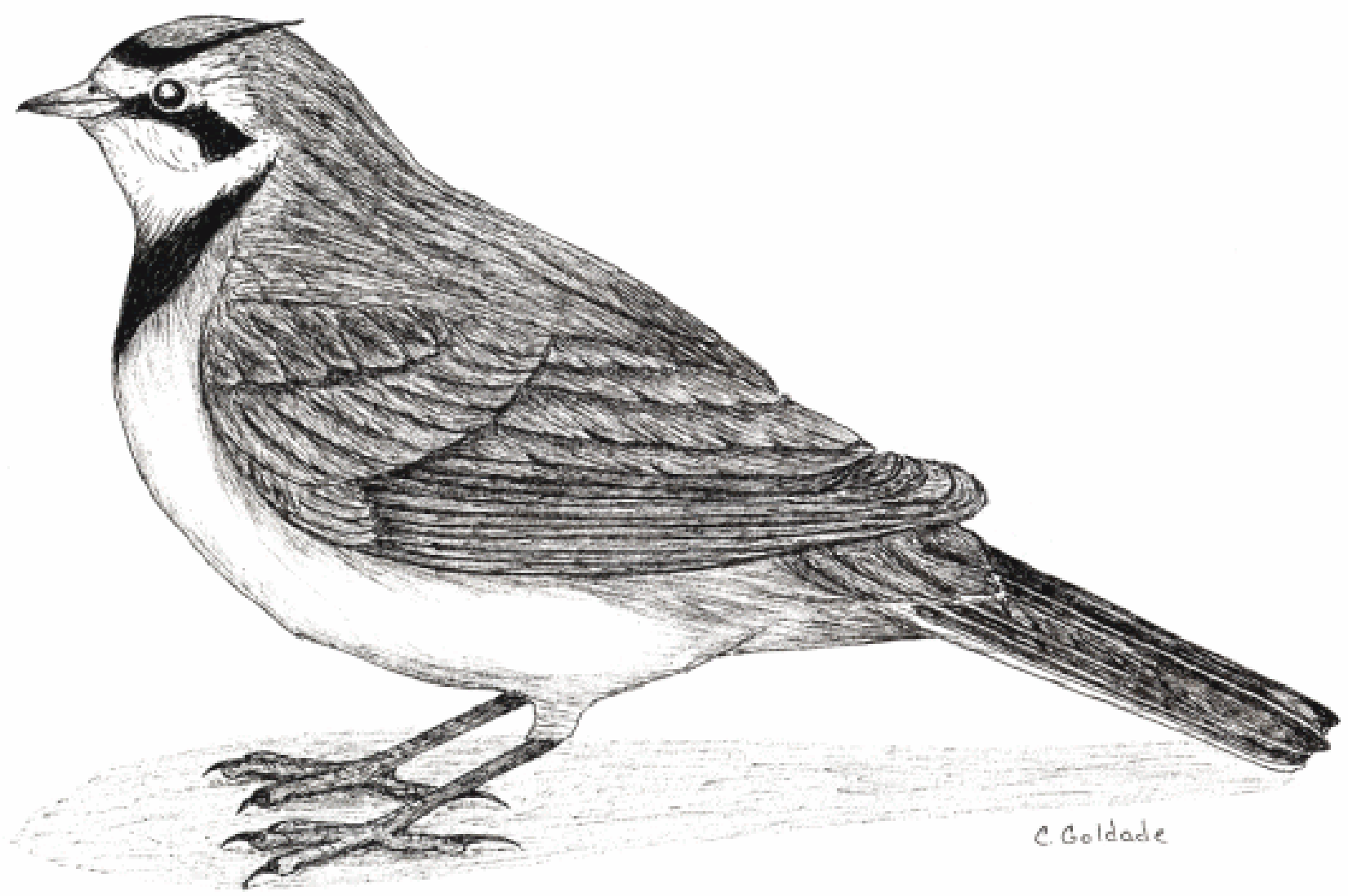

Grasslands Ecosystem Initiative

Northern Prairie Wildlife Research Center

U.S. Geological Survey

Jamestown, North Dakota 58401 
This report is one in a series of literature syntheses on North American grassland birds. The need for these reports was identified by the Prairie Pothole Joint Venture (PPJV), a part of the North American Waterfowl Management Plan. The PPJV recently adopted a new goal, to stabilize or increase populations of declining grassland- and wetland-associated wildlife species in the Prairie Pothole Region. To further that objective, it is essential to understand the habitat needs of birds other than waterfowl, and how management practices affect their habitats. The focus of these reports is on management of breeding habitat, particularly in the northern Great Plains.

Suggested citation:

Dinkins, M. F., A. L. Zimmerman, J. A. Dechant, B. D. Parkin, D. H. Johnson, L. D. Igl, C. M. Goldade, and B. R. Euliss. 2000 (revised 2002). Effects of management practices on grassland birds: Horned Lark. Northern Prairie Wildlife Research Center, Jamestown, ND. 34 pages.

Species for which syntheses are available or are in preparation:

American Bittern

Mountain Plover

Marbled Godwit

Long-billed Curlew

Willet

Wilson's Phalarope

Upland Sandpiper

Greater Prairie-Chicken

Lesser Prairie-Chicken

Northern Harrier

Swainson's Hawk

Ferruginous Hawk

Short-eared Owl

Burrowing Owl

Horned Lark

Sedge Wren

Loggerhead Shrike

Sprague's Pipit
Grasshopper Sparrow

Baird's Sparrow

Henslow's Sparrow

Le Conte's Sparrow

Nelson's Sharp-tailed Sparrow

Vesper Sparrow

Savannah Sparrow

Lark Sparrow

Field Sparrow

Clay-colored Sparrow

Chestnut-collared Longspur

McCown's Longspur

Dickcissel

Lark Bunting

Bobolink

Eastern Meadowlark

Western Meadowlark

Brown-headed Cowbird 


\section{EFFECTS OF MANAGEMENT PRACTICES ON GRASSLAND BIRDS:}

\section{HORNED LARK}

Meghan F. Dinkins, Amy L. Zimmerman, Jill A. Dechant, Barry D. Parkin, Douglas H. Johnson, Lawrence D. Igl, Christopher M. Goldade, and Betty R. Euliss

Series Coordinator: Douglas H. Johnson Series Assistant Coordinator: Lawrence D. Igl

Reviewer: Robert C. Beason

Range Map: Jeff T. Price

Cover Art: Christopher M. Goldade

Major Funding: Prairie Pothole Joint Venture, U.S. Fish and Wildlife Service U.S. Geological Survey

Funding also provided by: U.S. Forest Service

The Nature Conservancy

\section{Collaborators:}

Louis B. Best, Iowa State University

Carl E. Bock, University of Colorado

Brenda C. Dale, Canadian Wildlife Service

Stephen K. Davis, Saskatchewan Wetland Conservation Corporation

James J. Dinsmore, Iowa State University

James K. Herkert, Illinois Endangered Species Protection Board

Fritz L. Knopf, Midcontinent Ecological Science Center

Rolf R. Koford, Iowa Cooperative Fish and Wildlife Research Unit

David R. C. Prescott, Alberta NAWMP Centre

Mark R. Ryan, University of Missouri

David W. Sample, Wisconsin Department of Natural Resources

David A. Swanson, Ohio Division of Wildlife

Peter D. Vickery, Massachusetts Audubon Society

John L. Zimmerman (retired), Kansas State University

January 2000

(revised January 2002) 


\section{ORGANIZATION AND FEATURES OF THIS SPECIES ACCOUNT}

Information on the habitat requirements and effects of habitat management on grassland birds were summarized from information in more than 4,000 published and unpublished papers. A range map is provided to indicate the relative densities of the species in North America, based on Breeding Bird Survey (BBS) data. Although birds frequently are observed outside the breeding range indicated, the maps are intended to show areas where managers might concentrate their attention. It may be ineffectual to manage habitat at a site for a species that rarely occurs in an area. The species account begins with a brief capsule statement, which provides the fundamental components or keys to management for the species. A section on breeding range outlines the current breeding distribution of the species in North America, including areas that could not be mapped using BBS data. The suitable habitat section describes the breeding habitat and occasionally microhabitat characteristics of the species, especially those habitats that occur in the Great Plains. Details on habitat and microhabitat requirements often provide clues to how a species will respond to a particular management practice. A table near the end of the account complements the section on suitable habitat, and lists the specific habitat characteristics for the species by individual studies. A special section on prey habitat is included for those predatory species that have more specific prey requirements. The area requirements section provides details on territory and home range sizes, minimum area requirements, and the effects of patch size, edges, and other landscape and habitat features on abundance and productivity. It may be futile to manage a small block of suitable habitat for a species that has minimum area requirements that are larger than the area being managed. The Brown-headed Cowbird (Molothrus ater) is an obligate brood parasite of many grassland birds. The section on cowbird brood parasitism summarizes rates of cowbird parasitism, host responses to parasitism, and factors that influence parasitism, such as nest concealment and host density. The impact of management depends, in part, upon a species' nesting phenology and biology. The section on breeding-season phenology and site fidelity includes details on spring arrival and fall departure for migratory populations in the Great Plains, peak breeding periods, the tendency to renest after nest failure or success, and the propensity to return to a previous breeding site. The duration and timing of breeding varies among regions and years. Species' response to management summarizes the current knowledge and major findings in the literature on the effects of different management practices on the species. The section on management recommendations complements the previous section and summarizes specific recommendations for habitat management provided in the literature. If management recommendations differ in different portions of the species' breeding range, recommendations are given separately by region. The literature cited contains references to published and unpublished literature on the management effects and habitat requirements of the species. This section is not meant to be a complete bibliography; a searchable, annotated bibliography of published and unpublished papers dealing with habitat needs of grassland birds and their responses to habitat management is posted at the Web site mentioned below.

This report has been downloaded from the Northern Prairie Wildlife Research Center WorldWide Web site, www.npwrc.usgs.gov/resource/literatr/grasbird/grasbird.htm. Please direct comments and suggestions to Douglas H. Johnson, Northern Prairie Wildlife Research Center, U.S. Geological Survey, 8711 37th Street SE, Jamestown, North Dakota 58401; telephone: 701253-5539; fax: 701-253-5553; e-mail: Douglas_H_Johnson@usgs.gov. 


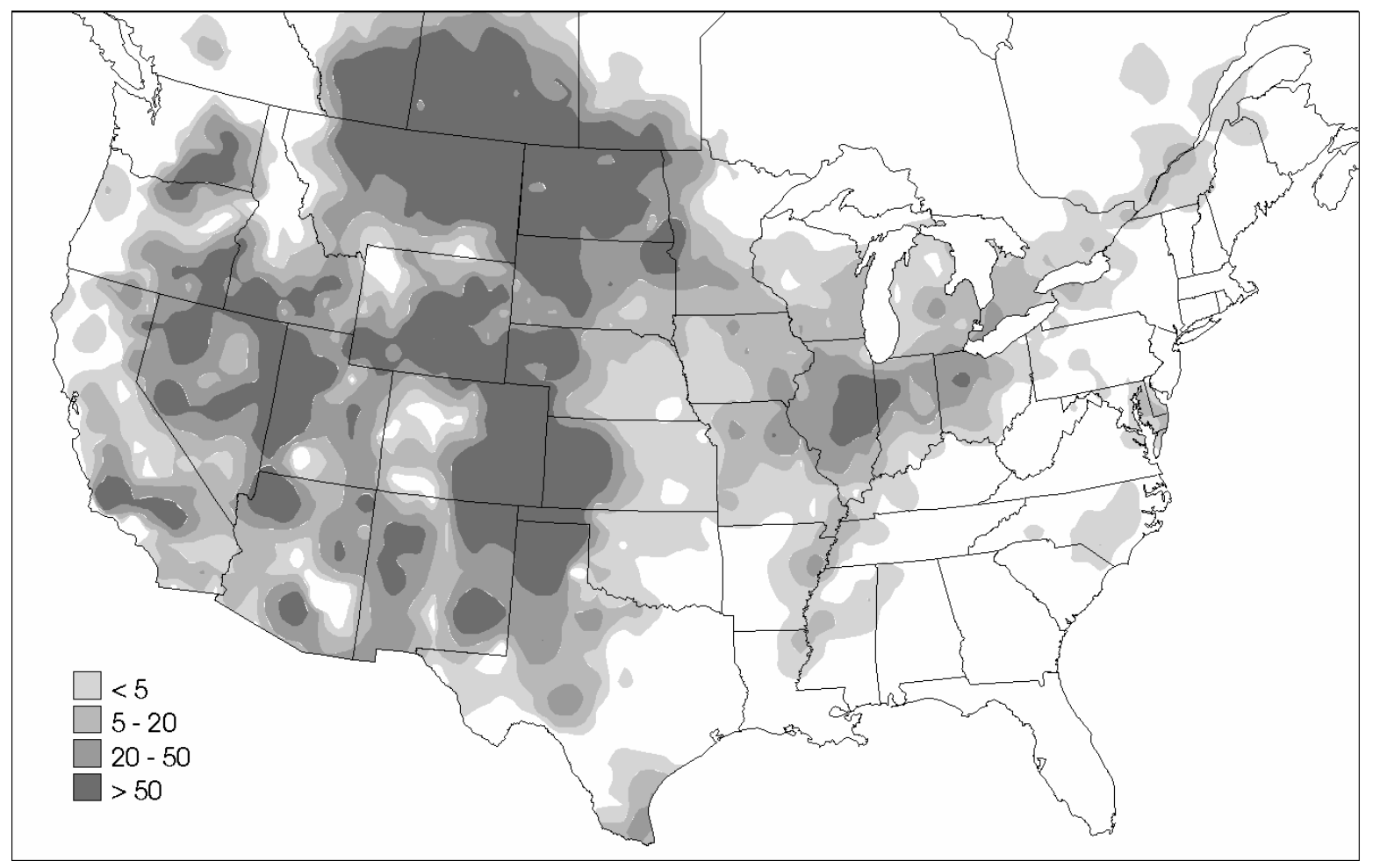

Figure. Breeding distribution of Horned Lark in the United States and southern Canada, based on Breeding Bird Survey data, 1985-1991. Scale represents average number of individuals detected per route per year. Map from Price, J., S. Droege, and A. Price. 1995. The summer atlas of North American birds. Academic Press, London, England. 364 pages.

Key to management is maintaining areas with short, sparse vegetation by burning, mowing, or grazing.

\section{Breeding range:}

There are 21 subspecies of Horned Lark (Beason 1995). Subspecies associated with the Great Plains include E.a. enthymia, E.a. leucolaema, and E.a. praticola. Horned Larks are yearround residents from southern British Columbia to southern Manitoba, south along the west coast of the United States to Mexico, and east to the east coast. Migratory populations of Horned Larks exist from northern British Columbia and Alaska, east to northern and eastern Quebec and Newfoundland, and also in southern Ontario and northern Michigan, Minnesota, and Wisconsin (National Geographic Society 1999). (See figure for the relative densities of the species in the United States and southern Canada, based on Breeding Bird Survey data.)

Suitable habitat:

Horned Larks prefer areas with short, sparse herbaceous vegetation with little or no woody vegetation (Beason 1970; Wiens 1973; Creighton 1974; Skinner 1974, 1975; Rotenberry and Wiens 1980; Dale 1983; Renken 1983; Sample 1989; Camp and Best 1993; Prescott and 
Murphy 1996; Davis and Duncan 1999; Martin and Forsyth 2003). Preferred habitats include cropland, herbaceous fencerows, road rights-of-way, pasture, recently cut hayland, and shrubsteppe (Bent 1942; Cassel 1952; Graber and Graber 1963; Speirs and Orenstein 1967; Beason 1970; Strong 1971; Porter and Ryder 1974; Stewart 1975; Ducey and Miller 1980; Ryder 1980; Kantrud 1981; Best and Hill 1983; Faanes 1983; Gremaud 1983; Castrale 1985; Kahl et al. 1985; Greer 1988; Best et al. 1990; Bryan and Best 1991; Camp and Best 1993; Johnson and Schwartz 1993a; Hartley 1994a,b; Patterson 1994; Anstey et al. 1995; Faanes and Lingle 1995; Kerley and Anderson 1995; King and Savidge 1995; Kent and Dinsmore 1996; Patterson and Best 1996; Best et al. 1997; Davis et al. 1997; McMaster 1998; McMaster and Davis 1998; Martin and Forsyth 2003). Occupied areas are characterized by moderate coverage (10-37\%) of bare ground (Speirs and Orenstein 1967, Skinner 1974, Dale 1983, Greer 1988, Sample 1989, Davis and Duncan 1999). Horned Larks may be present in newly seeded dense nesting cover (DNC) (Prescott and Murphy 1999), but relatively few if any Horned Larks were observed in established Conservation Reserve Program lands (CRP), Permanent Cover Program (PCP) lands, or DNC (Renken and Dinsmore 1987; Dale 1992, 1993; Johnson and Schwartz 1993a,b; Hartley 1994a,b; Johnson and Igl 1995; Patterson and Best 1996; Best et al. 1997). PCP was a Canadian program that paid farmers to seed highly erodible land to perennial cover; it differed from CRP in that haying and grazing were allowed annually in PCP.

In Colorado, Kansas, Montana, Nebraska, Oklahoma, Texas, and Wyoming, Horned Lark abundance was negatively correlated with percent forb cover, maximum vegetation height, and height of emergent forb and shrub cover (Rotenberry and Wiens 1980). In northcentral Colorado, mean vegetation measurements for occupied areas were $65 \%$ cover of short grasses (e.g., blue grama [Bouteloua gracilis] and buffalo grass [Buchloe dactyloides]), 2\% cover of mid-grasses (e.g., slimspike three-awn [Aristida longiseta], western wheatgrass [Pascopyrum smithii], little bluestem [Schizachyrium scoparium]), 6\% sedge (Carex spp.) cover, 7\% forb cover, $2 \%$ cactus cover, $0.8 \%$ shrub cover, $17 \%$ bare ground, $1 \%$ rock cover, and $7.2 \mathrm{~cm}$ mean vegetation height (Creighton 1974). In another Colorado study, Bock et al. (1999) compared the abundance of Horned Larks between upland (mixed-grass prairie) and lowland (tallgrass prairie or tame hayland) grassland plots. Horned Larks were significantly more abundant on upland than on lowland plots. In mixed-grass pastures in North Dakota, Horned Lark density was higher in pastures with $<10 \%$ cover of western snowberry (Symphoricarpos occidentalis) and silverberry (Elaeagnus commutata) than in pastures with 30-80\% cover of these shrubs (Arnold and Higgins 1986). The highest densities of Horned Larks occurred on transects with the lowest height and density of vegetation, regardless of the presence or absence of shrubs. Horned Larks in Saskatchewan occupied areas having little or no vegetation or litter (Dale 1983, Davis and Duncan 1999). Based on vegetation at nest sites in Saskatchewan, Horned Lark occurrence was positively associated with number of contacts of narrow-leaved ( $<5 \mathrm{~mm}$ wide) grasses $\leq 10 \mathrm{~cm}$ high and was negatively associated with vegetation height (SWCC 1997). In Alberta, the species preferred short grass that was uniform in height (Prescott and Murphy 1996).

Breeding habitat in Missouri cropland consisted of shallow $(<0.4 \mathrm{~cm})$, sparse $(<25 \%)$ litter cover, short $(<10 \mathrm{~cm})$ vegetation, and no woody stems (Kahl et al. 1985). Skinner (1974) found that Horned Larks in Missouri used areas of bare ground caused by cattle and American bison (Bison bison) disturbances. In Illinois, pasture and alfalfa (Medicago sativa) hayland were used only in early spring (prior to 5 May), when vegetation was short and sparse (Gremaud 1983). In Illinois cropland, territory density was highest in hay stubble or corn stubble fields than in plowed fields (Beason and Franks 1974). Beason (1970) found territories were densest in 
disced cropland and recently cut hayfields (with vegetation heights of about $10 \mathrm{~cm}$ ). Nests in cropland and hayland were placed on the ground in depressions, usually on the leeward side of a protective tuft of grass, rock, or other object in a barren area. Nests in Colorado often were found near cowpies (Porter and Ryder 1974, Ryder 1980, With and Webb 1993). Nests in North Dakota occurred in shallow depressions on bare or sparsely vegetated ground (Stewart 1975). In Iowa, the use of rowcrop fields significantly increased as their proximity to woody habitats decreased (Gremaud 1983). Horned Larks were common in strip-intercropped fields (i.e., planting rowcrops, legumes, and small grains in a series of adjacent, narrow strips) in Iowa (Stallman and Best 1996). In Nebraska, Horned Larks were absent from areas of extensive corn production, possibly because the timing of crop planting disrupted nesting activity (Faanes and Lingle 1995). Horned Larks in Indiana preferred conventionally tilled (fields tilled in the spring prior to planting) fields over no-tillage fields (fields untilled between harvest and planting with seed planted directly into crop residue) (Castrale 1985). In Alberta, short vegetation appeared to be a factor in early-season preference for cropland (Martin and Forsyth 2003). Short vegetation also was associated with higher numbers of productive territories and higher productivity when compared to areas of taller vegetation. Breeding territories were observed in both spring- and winter-wheat fields regardless of whether conventional or conservation tillage was used. Conventional tillage was defined as multiple cultivations prior to planting; conservation tillage was defined as planting directly into the previous year's stubble. A table near the end of the account lists the specific habitat characteristics for Horned Larks by study.

\section{Area requirements:}

In Colorado, Horned Lark territories in lightly grazed shortgrass pastures ranged from 0.3 to 1.5 ha and averaged 0.7 ha (Boyd 1976). Territories in heavily summer- and winter-grazed shortgrass pastures in Colorado ranged from 1.0 to 1.7 ha and averaged 1.5 ha (Wiens 1970, 1971). Territories in mixed-grass pasture and idle mixed-grass averaged 1.1 ha and 1.6 ha, respectively (Wiens 1971). In midwestern cropland, territory sizes ranged from 0.6 to 3.1 ha with an average of 1.6 ha (Beason and Franks 1974). Territory sizes in disced cropland and tame hayland ranged in size from 1.0 to 2.5 ha (Beason 1970). Bent (1942) reported a Horned Lark territory in Illinois that was only $81 \mathrm{~m}^{2}$ (0.008 ha). In tallgrass prairie fragments in Illinois, Horned Larks were found in patches $<10$ ha (Herkert 1991).

No studies have investigated a relationship between patch size and nest success or patch size and rates of brood parasitism by Brown-headed Cowbirds (Molothrus ater). Bock et al. (1999) compared the abundance of Horned Larks between interior and edge locations. Edge was defined as the interface between suburban development and upland or lowland habitat, and interior locations were $200 \mathrm{~m}$ from edge. Horned Larks occurred more frequently on interior plots than on edge plots but the difference was not significant due to high variation in numbers of Horned Larks among plots.

\section{Brown-headed Cowbird brood parasitism:}

The Horned Lark is an infrequent victim of the Brown-headed Cowbird (Friedmann 1963, Friedmann et al. 1977). Parasitism rates vary from 0\% of 163 nests (Maher 1973) to 60\% of 84 nests (Koford et al. 2000). Refer to Table 1 in Shaffer et al. (2003) for rates of cowbird brood parasitism. Horned Larks may be multiply-parasitized (Peabody 1899, Robbins 1949, Friedmann 1963, SWCC 1997, Koford et al. 2000). In Kansas and North Dakota, parasitism in initial clutches may have been less than in subsequent clutches because first clutches were laid 
before the onset of the breeding season of Brown-headed Cowbirds (Hill 1976, Koford et al. 2000). In North Dakota, no early nests (discovered prior to 15 May) were parasitized, but 50 of 84 (60\%) nests found after 15 May were parasitized (Koford et al. 2000). No parasitism was observed in eight initial clutches laid from mid-March to mid-April in western Kansas, but 14 of 22 second clutches were parasitized from mid-May to mid-June (Hill 1976). In the Great Plains, the breeding season of the Brown-headed Cowbird generally extends from early May to late July and peaks from late May to mid-July (Stewart 1975, Ortega 1998).

Breeding-season phenology and site fidelity:

Horned Larks may be year-round residents in all but the most northern parts of their breeding range (Beason 1995). Horned Larks begin arriving on their breeding range in large numbers from late February to late March and depart from late October to late November (Maher 1973, Stewart 1975, Salt and Salt 1976, Faanes 1981, Janssen 1987). Peak nesting in North Dakota occurred from late April to late July (Stewart 1975). Dubois (1935) noted two peaks in nesting activity in Montana, one at the end of April and another in early June. Peak nesting activity in Colorado occurred from April to early May (Creighton 1974). The species has exhibited both breeding-site and mate fidelity (George 1952, Ryder 1972, Boyd 1976). In Michigan, six of 12 banded adults returned as breeders the year following banding (George 1952). In Colorado, six of 15 banded adults were recaptured at the banding site the following year (Ryder 1972). Two banded males returned to the same study area the year following banding, but held different territories. In another Colorado study, 23 of 35 females and 23 of 36 males returned the year following banding (Boyd 1976). An additional two males were present on the previous year's territories in February and March but may have perished in a March snowstorm. Only one of the 23 males did not use the same territory as was used the previous year. Almost one half of the 23 returning females returned to the same mate the year following banding. Six of 136 Horned Larks marked as juveniles returned to breed on the study area. Also in Colorado, a male Horned Lark was resighted six years later in the same general area in which he was banded (Clapp et al. 1983).

Horned Larks raise up to three broods per season (Peabody 1899; George 1952; Maher 1973, 1974; Porter and Ryder 1974; Boyd 1976; Salt and Salt 1976). In Saskatchewan, the average number of clutches produced per female was estimated at two or three; some individuals produced up to five clutches (Maher 1973). Renesting is common after the failure of an initial nesting attempt (George 1952, Maher 1973).

\section{Species response to management:}

Horned Larks were present in South Dakota mixed-grass areas 1 mo postburn but were absent from unburned areas (Huber and Steuter 1984). In native rough fescue (Festuca scabrella) grasslands in Saskatchewan, breeding Horned Larks were present in low numbers (ranging from 0.02 to 0.06 birds/ha) in both a fall-burned plot and an unburned plot (Pylypec 1991). In Saskatchewan mixed-grass prairie that was burned in late summer, peak densities of Horned Larks were recorded 2 yr postburn (Maher 1973). In Wyoming, Kerley and Anderson (1995) observed Horned Larks in burned shrubsteppe.

In North Dakota, Horned Larks avoided a mixed-grass hayland that had been mowed during the previous year (Kantrud 1981). Horned Larks were not present in Colorado hayland, which had been flood-irrigated during spring and early summer, mowed during July, and occasionally grazed by cattle during fall and winter (Bock et al. 1995, Bock et al. 1999). In 
Illinois, Horned Larks were present in hayland composed of a mixture of native and tame vegetation (Graber and Graber 1963). Horned Larks in another Illinois study were common in a tame hayfield (vegetation height was $<10 \mathrm{~cm}$ ) early (March through May) in the breeding season, but abandoned the hayfield by early June, presumably due to the growth of vegetation (Beason 1970). Horned Larks became abundant in the hayfield after it was cut (vegetation height after cutting was 10-15 cm) in mid-June, although it appeared that no territories were established. By early July, vegetation in the hayfield had grown to $40 \mathrm{~cm}$ tall and the birds abandoned the field. Horned Larks occurred in tame hayland in Minnesota and Wisconsin (Faanes 1981). In Saskatchewan, Horned Larks were common in hayland that was mowed once annually in July; surveys were conducted just prior to mowing (Dale et al. 1997).

In shortgrass pastures in Colorado, Horned Larks preferred heavily grazed over lightly or moderately grazed pastures (Giezentanner and Ryder 1969; Ryder and Cobb 1969; Giezentanner 1970a,b; Ryder 1980). Wiens (1970) found that Horned Larks in Colorado preferred heavily winter-grazed sites over heavily summer-grazed sites for breeding. In North Dakota mixed-grass prairie, Horned Larks were found on twice-over rotation pastures, short-duration pastures, and season-long grazing pastures (Messmer 1990). Short-duration grazing involved a system of pastures rotated through a grazing schedule of about 1 wk grazed and 1 mo ungrazed, repeated throughout the season. Twice-over rotation involved grazing a number of pastures twice per season, with about a 2-mo rest in between grazing. Horned Larks preferred silty range sites that were characterized by loamy soils, 1-15\% slope, mean grass coverage ranging from 17 to 65\%, low shrub cover, and moderate to high litter cover; maximum vegetation height ranged from 50 to $70 \mathrm{~cm}$ and average litter depth ranged from 3.8 to $9.1 \mathrm{~cm}$. Horned Larks also were present in shallow-to-gravel sites that were characterized by shallow, coarse-textured soil, sparse cover, and reduced litter. In North Dakota, areas mowed or grazed by sheep had fewer shrubs than areas not mowed or grazed; Horned Larks preferred these areas because of reduced shrub density (Higgins 1986). In Missouri, Horned Larks were most common in heavily grazed native or tame pastures, followed by moderately grazed pastures; they were absent from idle grasslands and haylands (Skinner 1974, 1975; Skinner et al. 1984). Vegetation that was $>30 \mathrm{~cm}$ tall was avoided. In Saskatchewan, nests were observed in moderately to heavily grazed shortgrass (Strong 1971). Anstey et al. (1995) in Saskatchewan and Prescott (1997) in Alberta found that Horned Larks preferred mixed-grass pastures over tame pastures. No preference, however, was exhibited between mixed-grass pastures and tame pastures in other studies from Alberta and Saskatchewan (Prescott and Wagner 1996, Davis et al. 1997, Sutter and Brigham 1998, Davis and Duncan 1999).

Horned Larks are more common in cropland than in CRP (Johnson and Schwartz 1993a, Patterson 1994, Johnson and Igl 1995). Horned Larks were not observed in CRP in Indiana, Iowa, Kansas, Michigan, Missouri, and Nebraska (Patterson 1994, Best et al. 1997). Horned Larks in Minnesota, Montana, North Dakota, and South Dakota were most frequently observed in CRP that had been planted to native grasses (Johnson and Schwartz 1993b). They were less frequently observed in CRP fields planted to introduced grasses and legumes, and were absent from wildlife food plots and tree plantings. Horned Larks were absent from tame DNC and idle mixed-grass in North Dakota (Renken and Dinsmore 1987). In Alberta, Horned Larks were present in newly seeded DNC (Prescott and Murphy 1999). In Saskatchewan, Horned Larks were not present in DNC or were present in low numbers compared with low nesting cover (bluegrass [Poa]/fescue [Festuca] mixture) and idle mixed-grass prairie (Dale 1992,1993; Hartley $1994 a, b)$. Also in Saskatchewan, Horned Larks were more abundant in cropland on 
conventional, minimum-tillage, and organic farmland than in DNC (Shutler et al. 2000). Presence of Horned Larks was negatively related to number of wetlands within $2.8 \mathrm{~km}^{2}$ of point counts and by area of woody vegetation. Horned Larks were not detected in wetlands or wetland margins. Horned Larks were common in PCP, but occurred significantly more frequently in cropland (McMaster 1998, McMaster and Davis 1998). The frequency of occurrence of Horned Larks in PCP was significantly higher in grazed PCP sites than in hayed PCP sites.

Horned Lark densities in Colorado, Idaho, North Dakota, Utah, and Wyoming were not influenced by use of malathion, carbaryl in oil, and carbaryl bait for grasshopper (Orthoptera) control (George et al. 1995). At the Pawnee National Grassland in Colorado, malathion and toxaphene were applied at rates of $0.6 \mathrm{~kg} / \mathrm{ha}$ and $1.1 \mathrm{~kg} / \mathrm{ha}$, respectively (McEwen and Ells 1975). Densities of Horned Larks were about 1 pair per ha before application of insecticides. Seventeen days after application, numbers of Horned Larks decreased about $30 \%$ on toxaphene plots, but remained stable on malathion and untreated plots. Nestlings were killed by toxaphene applications. Mean toxaphene level of 13 Horned Larks collected between 1 and $28 \mathrm{~d}$ postspray for analysis of residue was 5.4 parts per million (ppm). At $58 \mathrm{~d}$, two birds had toxaphene residues of 4.6 and $4.1 \mathrm{ppm}$. At $85 \mathrm{~d}$, two birds had toxaphene residues of 2.3 and $2.9 \mathrm{ppm}$. Two dead meadowlarks contained toxaphene residues of 4.5 and $2.7 \mathrm{ppm}$. On malathion plots, only Horned Larks collected through $31 \mathrm{hr}$ postspray contained measurable $(\geq 0.4 \mathrm{ppm})$ wholebody residues. Four Horned Larks from the untreated area contained 0.5 to $2.0 \mathrm{ppm}$ toxaphene, indicating insecticide drift. No malathion residue was found in two birds from untreated plots. In New Mexico, toxaphene applied at $1.1 \mathrm{~kg} /$ ha caused mortality in Horned Larks and a decline in numbers (McEwen et al. 1972). No effects were observed from applications of $448 \mathrm{~g} / \mathrm{ha}$ carbaryl or $476 \mathrm{~g} / \mathrm{ha}$ malathion. Horned Larks numbers declined significantly on guthion-treated plots at the $280 \mathrm{~g} /$ ha application.

In Montana, numbers of Horned Larks were unaffected by application rates of $175 \mathrm{~g} / \mathrm{ha}$ of BAY $7748 *^{* 1}$ (phenylglyoxylonitrile oxime 0,0-diethyl phosphorothioate) (McEwen et al. 1972). Rates of 322 and $651 \mathrm{~g} /$ ha caused significant declines in Horned Lark numbers between pre- and post-spray censuses. Horned Lark numbers declined significantly on areas sprayed with 441 and $672 \mathrm{~g} / \mathrm{ha}$ applications of fenitrothion. In Wyoming, diazinon applied at 350-560 g/ha caused mortality in Horned Larks and a significant decline in numbers (McEwen et al. 1972). No significant declines in Horned Larks were caused by Mobam* (benzo [b]thien-4-yl methylcarbamate) applied at a rate of $210 \mathrm{~g} / \mathrm{ha}$. In Montana and Wyoming, numbers did not decline significantly with 140, 210, or $280 \mathrm{~g} /$ ha rates of Baygon* (o-isopropoxyphenyl methylcarbamate) (McEwen et al. 1972). In Wyoming, Horned Lark mortality was observed after fenthion, a chemical used to control mosquitoes (Culicidae), was aerially applied at a rate of $47 \mathrm{~g} / \mathrm{ha}$ to an irrigated meadow (DeWeese et al. 1983). Applications of chlorpyrifos on wheat fields (applied at rates of $1.0 \mathrm{~kg}$ in $18.9 \mathrm{~L}$ water/ha and $0.56 \mathrm{~kg}$ in $18.9 \mathrm{~L}$ water/ha) in Montana resulted in reduced cholinesterase activity in the brains of Horned Larks compared to a control group (McEwen et al. 1986).

Numbers of Horned Larks in Wyoming shrubsteppe were significantly higher in areas that were treated 20-22 yr previous to the study with 2,4-D to remove sagebrush than in untreated (i.e., unburned and not sprayed with herbicides) areas (Kerley and Anderson 1995).

\footnotetext{
*References to chemical trade names does not imply endorsement of commercial products by the Federal Government.
} 
Untreated areas contained higher shrub density, higher percent shrub cover, and taller shrubs than treated areas. Grazing intensity also was lower on untreated areas. In Ontario corn fields, the mean number of Horned Larks did not differ between pre- and post-applications of the granular insecticides fonofos and terbufos, which are used to control corn rootworm (Diabrotica spp.), or between treated fields and control fields (Knapton and Mineau 1995). In areas managed for lowbush blueberries (Vaccinium angustifolium) in Maine, Horned Larks were present only in areas recently sprayed with the herbicide hexazinone at a rate of $4 \mathrm{~kg} / \mathrm{ha}$ (Vickery 1993). Horned Larks preferred the sparse vegetation cover.

Clark and Karr (1979) studied the effects of roads and interstate highways on the density of Horned Larks in central Illinois. They found that the density of Horned Larks increased with distance from the road or highway. In a Saskatchewan study that examined whether the abundance of grassland birds differed between roadsides and trailsides, abundance of Horned Larks was not significantly different along trailsides than along roadsides (Sutter et al. 2000). Roads were defined as traveling surfaces with adjacent drainage ditches planted to smooth brome (Bromus inermis) and ending with a fence 11-18 $\mathrm{m}$ from the traveling surface. Trails were defined as a single pair of wheel ruts visually indistinct from surrounding habitat in terms of plant structure and composition. Habitat along roads and trails were parcels of lightly to moderately grazed native prairie $>256$ ha.

\section{Management recommendations:}

Burn in the spring to reduce woody species (Skinner et al. 1984).

Burning, mowing, or grazing can be used interchangeably to create short, sparse vegetation that Horned Larks prefer (Skinner 1974, 1975; Huber and Steuter 1984; Skinner et al. 1984).

Control shrub growth in mixed-grass pastures in North Dakota by allowing mowing or grazing by sheep (Arnold and Higgins 1986).

In mesic areas, allow moderate grazing to increase habitat patchiness and bird diversity (Skinner 1974, 1975; Ryder 1980; Skinner et al. 1984).

When pest management is required, use only rapidly degrading chemicals of low toxicity to nontarget organisms and apply at the lowest application rates possible (McEwen et al. 1972). Avoid pest outbreaks by maintaining range in good condition. Overgrazed and drought-affected areas tend to be more prone to insect outbreaks.

Reduce amount of grassland edge near suburban interfaces (Bock et al. 1999).

Road construction plans should consider the effects of roads on bird densities in rights-of-way and $\leq 500 \mathrm{~m}$ from rights-of-way (Clark and Karr 1979). 
Table. Horned Lark habitat characteristics.

\begin{tabular}{|c|c|c|c|}
\hline Author(s) & Location(s) & Habitat(s) Studied* & Species-specific Habitat Characteristics \\
\hline Anstey et al. 1995 & Saskatchewan & $\begin{array}{l}\text { Cropland, mixed-grass } \\
\text { pasture, tame hayland, } \\
\text { tame pasture }\end{array}$ & $\begin{array}{l}\text { Were observed most frequently in cropland; } \\
\text { preferred native over tame pastures; preferred } \\
\text { moderately and heavily grazed pastures; abundance } \\
\text { was negatively associated with shrubs and dead } \\
\text { vegetation } 20-100 \mathrm{~cm} \text { tall }\end{array}$ \\
\hline Arnold and Higgins 1986 & North Dakota & $\begin{array}{l}\text { Mixed-grass hayland, } \\
\text { mixed-grass pasture }\end{array}$ & $\begin{array}{l}\text { Occurred at higher densities in areas with }<10 \% \\
\text { cover of western snowberry (Symphoricarpos } \\
\text { occidentalis) and silverberry (Elaeagnus commutata) } \\
\text { than in pastures with } 30-80 \% \text { cover of these shrubs; } \\
\text { highest densities occurred in heavily grazed areas of } \\
\text { low height/density, regardless of the presence or } \\
\text { absence of shrubs }\end{array}$ \\
\hline Beason 1970 & Illinois & Cropland, tame hayland & $\begin{array}{l}\text { Territory density was highest in disced cropland and } \\
\text { an alfalfa (Medicago sativa) hayfield (vegetation } \\
\text { height in the hayfield was about } 10 \mathrm{~cm} \text { ); by early } \\
\text { June, the hayfield was abandoned, presumably due to } \\
\text { the growth of vegetation; the hayfield was } \\
\text { recolonized after the hay was cut (to about } 10 \text { or } 15 \\
\mathrm{~cm} \text { ) in mid-June, although no territories were } \\
\text { established at this time; by early July, vegetation in } \\
\text { the hayfield had grown to } 40 \mathrm{~cm} \text { and the field was } \\
\text { abandoned }\end{array}$ \\
\hline Beason and Franks 1974 & Illinois & $\begin{array}{l}\text { Cropland, hayland, } \\
\text { idle tame }\end{array}$ & $\begin{array}{l}\text { Occurred at higher densities in hay stubble or corn } \\
\text { stubble than in plowed fields }\end{array}$ \\
\hline Best and Hill 1983 & Iowa & Cropland & $\begin{array}{l}\text { Occurred in herbaceous fencerows in the spring and } \\
\text { summer }\end{array}$ \\
\hline
\end{tabular}




\begin{tabular}{|c|c|c|c|}
\hline Best et al. 1997 & $\begin{array}{l}\text { Indiana, } \\
\text { Iowa, } \\
\text { Kansas, Michigan, } \\
\text { Missouri, } \\
\text { Nebraska }\end{array}$ & $\begin{array}{l}\text { Conservation Reserve } \\
\text { Program (CRP; burned } \\
\text { seeded-native, burned } \\
\text { seeded-native/tame, } \\
\text { burned tame, idle } \\
\text { seeded-native, idle } \\
\text { tame/seeded-native, } \\
\text { idle tame, seeded- } \\
\text { native/tame hayland, } \\
\text { tame hayland), cropland }\end{array}$ & Nested in rowcrop fields but not in CRP \\
\hline $\begin{array}{l}\text { Bock et al. 1995, } \\
\text { Bock et al. } 1999\end{array}$ & Colorado & $\begin{array}{l}\text { Idle mixed-grass, idle } \\
\text { tallgrass, mixed-grass } \\
\text { pasture, tallgrass } \\
\text { pasture, tame hayland }\end{array}$ & $\begin{array}{l}\text { Were present in uplands and absent from tallgrass or } \\
\text { hayland; hayland had been flood-irrigated during } \\
\text { spring and early summer, mowed during July, and } \\
\text { occasionally was grazed by cattle during fall and } \\
\text { winter }\end{array}$ \\
\hline Boyd 1976 & Colorado & Shortgrass pasture & $\begin{array}{l}\text { Sang from road centers, cowpies, or fence posts; } \\
\text { smallest territories were associated with an area that } \\
\text { had a level playa and consisted of medium and fine } \\
\text { textured soil; vegetation in this shortgrass habitat } \\
\text { included blue grama (Bouteloua gracilis), buffalo } \\
\text { grass (Buchloe dactyloides), scattered clumps of } \\
\text { slimspike three-awn (Aristida longiseta), and shrubs } \\
\text { ground nests were sheltered by vegetation (e.g., } \\
\text { grama [Bouteloua], three-awn [Aristida], rabbitbrush } \\
\text { [Chrysosamnus], and prickly pear [Opuntia]) or } \\
\text { cowpies }\end{array}$ \\
\hline Bryan and Best 1991 & Iowa & $\begin{array}{l}\text { Cropland, idle tame, } \\
\text { tame hayland }\end{array}$ & $\begin{array}{l}\text { Densities were higher in grassed waterways than in } \\
\text { cropland }\end{array}$ \\
\hline Camp and Best 1993 & Iowa & Burned seeded-native & Were common in roadsides; abundance in roadsides \\
\hline
\end{tabular}




\begin{tabular}{|c|c|c|c|}
\hline & & $\begin{array}{l}\text { tallgrass/tame, burned } \\
\text { tame, cropland, idle } \\
\text { seeded-native } \\
\text { tallgrass/tame, idle tame }\end{array}$ & increased with greater forb cover \\
\hline Cassel 1952 & Colorado & $\begin{array}{l}\text { Montane meadow, } \\
\text { shortgrass pasture, } \\
\text { shrubsteppe, woodland }\end{array}$ & $\begin{array}{l}\text { Were found in heavily grazed blue grama; occurred } \\
\text { in a wide variety of habitats, from plains to alpine } \\
\text { meadow }\end{array}$ \\
\hline Castrale 1985 & Indiana & Cropland & $\begin{array}{l}\text { Occurred in conventionally tilled cropland but not in } \\
\text { untilled cropland }\end{array}$ \\
\hline Creighton 1974 & Colorado & $\begin{array}{l}\text { Mixed-grass pasture, } \\
\text { shortgrass pasture }\end{array}$ & $\begin{array}{l}\text { Nesting habitat was characterized by sparse } \\
\text { vegetation dominated by buffalo grass and blue } \\
\text { grama; mean vegetation values for occupied areas } \\
\text { were } 65 \% \text { shortgrass (e.g., blue grama and buffalo } \\
\text { grass) cover, } 2 \% \text { mid-grass (e.g., western wheatgrass } \\
\text { [Pascopyrum smithii], slimspike three-awn, little } \\
\text { bluestem [Schizachyrium scoparium], needle-and- } \\
\text { thread [Stipa comata]) cover, } 6 \% \text { sedge (Carex spp.) } \\
\text { cover, } 7 \% \text { forb cover, } 2 \% \text { cactus cover, } 0.8 \% \text { shrub } \\
\text { cover, } 17 \% \text { bare ground, and } 1 \% \text { rock cover ; mean } \\
\text { vegetation height was } 7.2 \mathrm{~cm} \text {; nests were not covered } \\
\text { by vegetation }\end{array}$ \\
\hline Dale 1983, 1984 & Saskatchewan & $\begin{array}{l}\text { Idle mixed-grass, } \\
\text { mixed-grass pasture }\end{array}$ & $\begin{array}{l}\text { Consistently chose areas of sparse, low vegetation in } \\
\text { grazed areas; grazing reduced density and height of } \\
\text { vegetation, which made habitat available earlier in } \\
\text { the breeding season, created favorable thermal } \\
\text { conditions, and provided foraging, displaying, and } \\
\text { nesting needs; occupied areas were characterized by } \\
5.6 \text { vertical vegetation contacts, } 5.5 \text { vegetation } \\
\text { contacts in first } 10 \mathrm{~cm}, 3.4 \mathrm{~cm} \text { forb height, } 1.0 \\
\text { vegetation contacts in last } 10 \mathrm{~cm}, 4.9 \mathrm{~mm} \text { litter }\end{array}$ \\
\hline
\end{tabular}




\begin{tabular}{|c|c|c|c|}
\hline & & & $\begin{array}{l}\text { depth, } 20.5 \% \text { dwarf shrub cover, } 41.5 \mathrm{~cm} \text { distance to } \\
\text { nearest forb, and } 9.8 \% \text { bare ground cover }\end{array}$ \\
\hline Dale 1992 & Saskatchewan & $\begin{array}{l}\text { Dense Nesting Cover } \\
\text { (DNC; idle seeded- } \\
\text { native, idle tame), idle } \\
\text { native, idle native/tame, } \\
\text { tame hayland }\end{array}$ & $\begin{array}{l}\text { Were more common in bluegrass (Poa)/fescue } \\
(\text { Festuca) than in tame DNC grasslands }\end{array}$ \\
\hline Dale 1993 & Saskatchewan & $\begin{array}{l}\text { DNC (idle tame), idle, } \\
\text { low nesting cover (idle } \\
\text { tame) }\end{array}$ & $\begin{array}{l}\text { Were observed in fallow fields; significantly more } \\
\text { Horned Larks occurred in low nesting cover than in } \\
\text { DNC }\end{array}$ \\
\hline Dale et al. 1997 & Saskatchewan & $\begin{array}{l}\text { Idle mixed-grass, idle } \\
\text { tame, tame hayland }\end{array}$ & $\begin{array}{l}\text { Occurred frequently in native grassland and in } \\
\text { annually hayed fields }\end{array}$ \\
\hline Davis and Duncan 1999 & Saskatchewan & $\begin{array}{l}\text { Mixed-grass pasture, } \\
\text { tame pasture }\end{array}$ & $\begin{array}{l}\text { Were equally frequent in native pastures as in tame } \\
\text { pastures (crested wheatgrass [Agropyron cristatum]); } \\
\text { occurrence in native or tame pastures was positively } \\
\text { associated with bare ground and fringed sagewort } \\
\text { (Artemisia frigida) and negatively associated with } \\
\text { vegetation height, litter depth, thick-spike } \\
\text { wheatgrass (Agropyron dasystachyum), and western } \\
\text { snowberry }\end{array}$ \\
\hline Davis et al. 1997 & Saskatchewan & $\begin{array}{l}\text { Cropland, hayland, } \\
\text { mixed-grass pasture, } \\
\text { tame pasture }\end{array}$ & $\begin{array}{l}\text { Were more abundant in cropland than in hayland, } \\
\text { mixed-grass pasture, or tame pasture; species was } \\
\text { equally abundant in tame pasture and native pasture }\end{array}$ \\
\hline Ducey and Miller 1980 & Nebraska & $\begin{array}{l}\text { Cropland, idle, mixed- } \\
\text { grass pasture, tame } \\
\text { hayland }\end{array}$ & Were observed in soybean and corn fields \\
\hline Faanes 1981 & $\begin{array}{l}\text { Minnesota, } \\
\text { Wisconsin }\end{array}$ & $\begin{array}{l}\text { Cropland, idle, idle } \\
\text { tallgrass/tame, shrub }\end{array}$ & $\begin{array}{l}\text { Used agricultural areas, such as hayfields, oat } \\
\text { stubble fields with very short vegetation, bare }\end{array}$ \\
\hline
\end{tabular}




\begin{tabular}{|c|c|c|c|}
\hline & & $\begin{array}{l}\text { carr, tame hayland, tame } \\
\text { pasture, wet meadow, } \\
\text { wetland, woodland }\end{array}$ & cultivated areas, and rowcrops \\
\hline Faanes 1983 & North Dakota & $\begin{array}{l}\text { Idle mixed-grass, } \\
\text { mixed-grass pasture, } \\
\text { woodland }\end{array}$ & $\begin{array}{l}\text { Nested in moderately to heavily grazed native } \\
\text { pastures and in fallow cropland adjacent to wooded } \\
\text { draws }\end{array}$ \\
\hline Faanes and Lingle 1995 & Nebraska & $\begin{array}{l}\text { Cropland, idle mixed- } \\
\text { grass, idle shortgrass, } \\
\text { idle tallgrass, pasture, } \\
\text { tame hayland, wet } \\
\text { meadow, wetland, } \\
\text { woodland }\end{array}$ & $\begin{array}{l}\text { Nested in upland prairie, wheat, alfalfa, corn, and } \\
\text { wet prairie; were largely absent from areas of } \\
\text { extensive corn production, possibly because the } \\
\text { timing of crop planting disrupted nesting activity }\end{array}$ \\
\hline Giezentanner $1970 a, b$ & Colorado & $\begin{array}{l}\text { Cropland, hayland, idle, } \\
\text { shortgrass pasture }\end{array}$ & $\begin{array}{l}\text { Were found in both summer and winter pastures that } \\
\text { were grazed at heavy, moderate, and light levels; } \\
\text { heavy grazing removed } 60 \% \text { of the annual plant } \\
\text { growth and resulted in pastures of uniform height; } \\
\text { moderate grazing removed } 40 \% \text { of the annual plant } \\
\text { growth and resulted in patches of grazed and } \\
\text { ungrazed areas; and light grazing removed } 20 \% \text { of } \\
\text { the annual plant growth and resulted in patches of } \\
\text { heavy grazing surrounded by areas of little or no } \\
\text { grazing; were most common in the heavily summer- } \\
\text { grazed area with sparse vegetation } 2.5-5.1 \mathrm{~cm} \text { high }\end{array}$ \\
\hline $\begin{array}{l}\text { Giezentanner and Ryder } \\
1969\end{array}$ & Colorado & Shortgrass pasture & $\begin{array}{l}\text { Were most abundant on heavily and moderately } \\
\text { summer-grazed pastures }\end{array}$ \\
\hline Graber and Graber 1963 & Illinois & $\begin{array}{l}\text { Cropland, hayland, idle, } \\
\text { idle grassland, tame } \\
\text { pasture, wetland, } \\
\text { woodland }\end{array}$ & $\begin{array}{l}\text { Density was highest in plowed fields, followed by } \\
\text { fields of alfalfa, red clover (Trifolium pratense), } \\
\text { soybean, corn, yellow sweet clover (Melilotus } \\
\text { officinalis), small-grain stubble, oats, ungrazed }\end{array}$ \\
\hline
\end{tabular}




\begin{tabular}{|c|c|c|c|}
\hline & & & $\begin{array}{l}\text { grassland, fallow, pastures, or hayland; as amount of } \\
\text { acreage in cropland increased, Horned Larks used } \\
\text { more cropland }\end{array}$ \\
\hline Greer 1988 & Wyoming & Mixed-grass pasture & $\begin{array}{l}\text { Nest sites were characterized by mean values of 22\% } \\
\text { lichen cover, } 2 \% \text { cowpie cover, } 8 \% \text { forb cover, } 7 \% \\
\text { shrub cover, } 1 \% \text { cactus cover, } 37 \% \text { bare ground } \\
\text { cover, } 26 \% \text { mixed-grass (e.g., needle-and thread } \\
\text { grass, western wheatgrass, Junegrass [Koeleria } \\
\text { pyramidata], Indian ricegrass [Oryzopsis } \\
\text { hymenoides], and bluegrasses [Poa spp.]) cover, } \\
15 \% \text { litter cover, } 23 \% \text { shortgrass (e.g., blue grama) } \\
\text { cover; } 23 \% \text { plant cover in first } 5 \text { cm; } 1.4 \text { total } \\
\text { vegetation contacts; } 61 \% \text { of } 21 \text { nests were placed on } \\
\text { the leeward side of shrubs }\end{array}$ \\
\hline Gremaud 1983 & Iowa & $\begin{array}{l}\text { Cropland, tame hayland, } \\
\text { tame pasture, woodland }\end{array}$ & $\begin{array}{l}\text { Abundance was higher in rowcrop than in } \\
\text { herbaceous habitats; use of rowcrops significantly } \\
\text { increased as the proximity to woody habitats } \\
\text { (woodland or brush) decreased; pastures and alfalfa } \\
\text { hayfields received little use once vegetation began to } \\
\text { grow following grazing or haying }\end{array}$ \\
\hline Griebel et al. 1998 & Nebraska & $\begin{array}{l}\text { Burned mixed-grass } \\
\text { pasture, mixed-grass } \\
\text { pasture }\end{array}$ & $\begin{array}{l}\text { Relative abundance did not differ between a burned } \\
\text { area grazed by American bison (Bison bison) and } \\
\text { areas grazed by cattle; within bison pastures, Horned } \\
\text { Lark abundances were not significantly different } \\
\text { between burned and unburned areas }\end{array}$ \\
\hline Hartley $1994 a, b$ & Saskatchewan & $\begin{array}{l}\text { Cropland, DNC (idle } \\
\text { seeded-native, idle } \\
\text { seeded-native/tame, idle } \\
\text { tame, idle tame } \\
\text { hayland), idle mixed- }\end{array}$ & $\begin{array}{l}\text { Were found in idle mixed-grass and cropland; more } \\
\text { common in cropland than in idle mixed-grass; absent } \\
\text { from DNC }\end{array}$ \\
\hline
\end{tabular}




\begin{tabular}{|c|c|c|c|}
\hline & & grass & \\
\hline Johnsgard 1980 & Nebraska & $\begin{array}{l}\text { Cropland, idle, idle } \\
\text { mixed-grass, idle } \\
\text { shortgrass, idle tallgrass, } \\
\text { mixed-grass pasture, } \\
\text { tallgrass pasture }\end{array}$ & Were found in native grasslands and cultivated fields \\
\hline $\begin{array}{l}\text { Johnson and Igl 1995, } \\
\text { Johnson and Schwartz } \\
1993 a\end{array}$ & $\begin{array}{l}\text { Minnesota, } \\
\text { Montana, } \\
\text { North Dakota, } \\
\text { South Dakota }\end{array}$ & $\begin{array}{l}\text { Cropland, CRP (idle } \\
\text { seeded-native, idle } \\
\text { tame) }\end{array}$ & Were more common in cropland than in CRP \\
\hline $\begin{array}{l}\text { Johnson and Schwartz } \\
1993 b\end{array}$ & $\begin{array}{l}\text { Minnesota, } \\
\text { Montana, } \\
\text { North Dakota, } \\
\text { South Dakota }\end{array}$ & $\begin{array}{l}\text { Cropland, CRP (idle } \\
\text { seeded-native, idle } \\
\text { tame) }\end{array}$ & $\begin{array}{l}\text { Densities were higher in CRP planted to native } \\
\text { grasses than in CRP planted to tame grasses }\end{array}$ \\
\hline Jones 1994 & Manitoba & $\begin{array}{l}\text { Cropland, DNC (idle } \\
\text { seeded-native, idle } \\
\text { tame), idle mixed-grass, } \\
\text { idle tame, tame hayland, } \\
\text { woodland }\end{array}$ & $\begin{array}{l}\text { Observed in highest abundance in cropland; also } \\
\text { found in hayland and idle mixed-grass }\end{array}$ \\
\hline Kahl et al. 1985 & Missouri & $\begin{array}{l}\text { Burned tallgrass, } \\
\text { cropland, idle, idle } \\
\text { tallgrass, tallgrass } \\
\text { hayland, tallgrass } \\
\text { pasture, woodland, } \\
\text { woodland edge }\end{array}$ & $\begin{array}{l}\text { Were found only in agricultural habitats; occupied } \\
\text { habitat had shallow }(<0.4 \mathrm{~cm}) \text { litter, short }(<0.10 \mathrm{~m}) \\
\text { ground vegetation, no woody stems, and sparse } \\
(<25 \%) \text { litter cover }\end{array}$ \\
\hline Kantrud 1981 & North Dakota & $\begin{array}{l}\text { Mixed-grass hayland, } \\
\text { mixed-grass pasture }\end{array}$ & $\begin{array}{l}\text { Avoided hayland that was mowed the previous year; } \\
\text { were most abundant in heavily grazed pasture }\end{array}$ \\
\hline Kantrud and Kologiski & Colorado, & Mixed-grass pasture, & Were most common in heavily grazed borollic \\
\hline
\end{tabular}




\begin{tabular}{|c|c|c|c|}
\hline 1982 & $\begin{array}{l}\text { Montana, } \\
\text { Nebraska, } \\
\text { North Dakota, } \\
\text { South Dakota, } \\
\text { Wyoming }\end{array}$ & $\begin{array}{l}\text { shortgrass pasture, } \\
\text { shrubsteppe }\end{array}$ & $\begin{array}{l}\text { aridisol soils, which were characterized by light } \\
\text { coloration, low organic matter, and low moisture } \\
\text { content during the growing season }\end{array}$ \\
\hline Karasiuk et al. 1977 & Alberta & Mixed-grass pasture & Observed in heavily grazed areas \\
\hline Kent and Dinsmore 1996 & Iowa & Cropland, pasture & Nested in pasture and cropland \\
\hline King and Savidge 1995 & Nebraska & $\begin{array}{l}\text { Burned tallgrass, } \\
\text { cropland, CRP (burned } \\
\text { seeded-native, idle } \\
\text { seeded-native, idle } \\
\text { tame, tame hayland), } \\
\text { idle tallgrass, tallgrass } \\
\text { hayland }\end{array}$ & Observed only in cropland \\
\hline Maher 1973 & Saskatchewan & $\begin{array}{l}\text { Burned mixed-grass, } \\
\text { idle mixed-grass, } \\
\text { mixed-grass hayland, } \\
\text { mixed-grass pasture }\end{array}$ & $\begin{array}{l}\text { Density was three times higher in grazed than } \\
\text { ungrazed grassland; in ungrazed grassland, } \\
\text { maintained relatively constant density between five } \\
\text { seasons; in burned grassland, highest density } \\
\text { occurred } 2 \text { yr postburn }\end{array}$ \\
\hline Maher 1974 & Saskatchewan & $\begin{array}{l}\text { Cropland, } \\
\text { idle mixed-grass, } \\
\text { mixed-grass pasture, } \\
\text { tame hayland, woodland }\end{array}$ & $\begin{array}{l}\text { Very common summer resident and occasional } \\
\text { permanent resident on grazed and ungrazed } \\
\text { grassland }\end{array}$ \\
\hline Martin and Forsyth 2003 & Alberta & Cropland, idle & $\begin{array}{l}\text { Breeding territories were established in almost every } \\
\text { spring-wheat field in both years, regardless of } \\
\text { whether conventional tillage or conservation tillage } \\
\text { was used; conventional tillage was defined as } \\
\text { multiple cultivations prior to planting; conservation }\end{array}$ \\
\hline
\end{tabular}




\begin{tabular}{|c|c|c|c|}
\hline & & & $\begin{array}{l}\text { tillage was defined as planting directly into the } \\
\text { previous year's stubble; breeding territories were } \\
\text { established in most winter-wheat fields under both } \\
\text { tillage regimes at some point during the season; } \\
\text { breeding territories were established in almost every } \\
\text { fallow field in both years, regardless of tillage } \\
\text { regime; early-season use of fields, number of } \\
\text { productive territories, and productivity were } \\
\text { negatively correlated with vegetation height }\end{array}$ \\
\hline $\begin{array}{l}\text { McMaster 1998, } \\
\text { McMaster and Davis } 1998\end{array}$ & $\begin{array}{l}\text { Alberta, Manitoba, } \\
\text { Saskatchewan }\end{array}$ & $\begin{array}{l}\text { Cropland, Permanent } \\
\text { Cover Program (PCP; } \\
\text { idle tame, tame hayland, } \\
\text { tame pasture) }\end{array}$ & $\begin{array}{l}\text { Were common within PCP sites but occurred } \\
\text { significantly more frequently in cropland; frequency } \\
\text { of occurrence was significantly higher in grazed PCP } \\
\text { sites than in hayed PCP sites }\end{array}$ \\
\hline Messmer 1990 & North Dakota & $\begin{array}{l}\text { Idle mixed-grass/tame, } \\
\text { mixed-grass/tame } \\
\text { hayland, mixed- } \\
\text { grass/tame pasture, wet- } \\
\text { meadow pasture }\end{array}$ & $\begin{array}{l}\text { Density was higher on the twice-over rotation } \\
\text { grazing system than short-duration grazing, season- } \\
\text { long grazing, and idle; no density differences were } \\
\text { exhibited among treatments } 4 \text { yr later; were found on } \\
\text { silty range sites or shallow-to-gravel sites of grazed } \\
\text { pastures; silty range sites were characterized by } \\
\text { mean values of } 17-65 \% \text { grass cover, } 1-4 \% \text { shrub } \\
\text { cover,18-59\% litter cover; } 50-70 \mathrm{~cm} \text { maximum } \\
\text { vegetation height and } 3.8-9.1 \mathrm{~cm} \text { litter depth; } \\
\text { shallow-to-gravel range sites were characterized by } \\
\text { sparse cover and reduced litter }\end{array}$ \\
\hline Owens and Myres 1973 & Alberta & $\begin{array}{l}\text { Cropland, idle mixed- } \\
\text { grass, mixed-grass } \\
\text { hayland, mixed-grass } \\
\text { pasture }\end{array}$ & Nested only in cultivated and grazed areas \\
\hline $\begin{array}{l}\text { Patterson 1994, } \\
\text { Patterson and Best } 1996\end{array}$ & Iowa & $\begin{array}{l}\text { Cropland, CRP (idle } \\
\text { tame, tame hayland) }\end{array}$ & $\begin{array}{l}\text { Nested in rowcrop fields; were not present in CRP, } \\
\text { nor were any nests found in CRP }\end{array}$ \\
\hline
\end{tabular}




\begin{tabular}{|c|c|c|c|}
\hline Porter and Ryder 1974 & Colorado & Shortgrass pasture & $\begin{array}{l}\text { Preferred heavily grazed pastures for nesting over } \\
\text { lightly or moderately grazed pastures }\end{array}$ \\
\hline Prescott 1997 & Alberta & $\begin{array}{l}\text { Cropland, hayland, } \\
\text { mixed-grass pasture, } \\
\text { shrubland, tame pasture, } \\
\text { woodland }\end{array}$ & $\begin{array}{l}\text { Were present in native mixed-grass, tame pastures, } \\
\text { hayland, sandhill prairie, fallow cropland, planted } \\
\text { cropland, and shelterbelts }\end{array}$ \\
\hline Prescott et al. 1993 & Alberta & $\begin{array}{l}\text { Cropland, DNC (idle } \\
\text { seeded-native), mixed- } \\
\text { grass pasture, tame } \\
\text { pasture, wetland }\end{array}$ & $\begin{array}{l}\text { Were common in delayed grazing pasture treatments, } \\
\text { created wetlands, early summer-grazed native } \\
\text { pastures, spring-grazed tame pastures, deferred (after } \\
15 \text { July) native pastures, and continuously grazed } \\
\text { native pastures }\end{array}$ \\
\hline Prescott and Murphy 1996 & Alberta & $\begin{array}{l}\text { Mixed-grass pasture, } \\
\text { tame pasture }\end{array}$ & $\begin{array}{l}\text { Frequency of occurrence was higher in native } \\
\text { pastures than tame pastures; in native pastures, } \\
\text { ordination results showed that the species appeared } \\
\text { in areas with moderate cover diversity, short grass, } \\
\text { and grass moderately uniform in height; principal } \\
\text { component analysis showed that in native pastures } \\
\text { the species reached highest abundance in short grass, } \\
\text { with low values of forb/grass ratio; in tame pastures, } \\
\text { highest abundances occurred in areas with low } \\
\text { herbaceous biomass and uniform herbaceous height; } \\
\text { in native pastures, preferred short, uniform grass; in } \\
\text { tame pastures, preferred little herbaceous biomass } \\
\text { and uniform herbaceous height }\end{array}$ \\
\hline $\begin{array}{l}\text { Prescott and Murphy } \\
1999\end{array}$ & Alberta & $\begin{array}{l}\text { Cropland, DNC (idle } \\
\text { seeded-native/tame) }\end{array}$ & Preferred cropland and newly seeded DNC \\
\hline Prescott and Wagner 1996 & Alberta & $\begin{array}{l}\text { Mixed-grass pasture, } \\
\text { tame pasture }\end{array}$ & Were abundant in mixed-grass and tame pastures \\
\hline
\end{tabular}




\begin{tabular}{|c|c|c|c|}
\hline Pylypec 1991 & Saskatchewan & $\begin{array}{l}\text { Burned mixed-grass, } \\
\text { idle mixed-grass }\end{array}$ & $\begin{array}{l}\text { Present in low numbers in burned and unburned } \\
\text { areas }\end{array}$ \\
\hline Renken 1983 & North Dakota & $\begin{array}{l}\text { DNC (idle tame), idle } \\
\text { mixed-grass, mixed- } \\
\text { grass pasture }\end{array}$ & $\begin{array}{l}\text { Occurred only in grazed areas; used plots had less } \\
\text { grass and forb cover than unused plots; used areas } \\
\text { had } 45 \% \text { grass cover, } 13.0 \% \text { forb cover, } 99 \% \text { litter } \\
\text { cover, } 0.7 \% \text { shrub cover, } 1.0 \% \text { bare ground, } \\
\text { effective vegetation height of } 5 \mathrm{~cm} \text {, and } 1.6 \mathrm{~cm} \text { litter } \\
\text { depth }\end{array}$ \\
\hline $\begin{array}{l}\text { Renken and Dinsmore } \\
1987\end{array}$ & North Dakota & $\begin{array}{l}\text { DNC (idle tame), idle } \\
\text { mixed-grass, mixed- } \\
\text { grass pasture }\end{array}$ & $\begin{array}{l}\text { Were observed in grazed plots, but were absent from } \\
\text { DNC or idle }\end{array}$ \\
\hline $\begin{array}{l}\text { Rotenberry and Wiens } \\
1980\end{array}$ & $\begin{array}{l}\text { Colorado, Kansas, } \\
\text { Montana, } \\
\text { Nebraska, } \\
\text { Oklahoma, } \\
\text { Oregon, } \\
\text { South Dakota, } \\
\text { Texas, } \\
\text { Washington, } \\
\text { Wisconsin, } \\
\text { Wyoming }\end{array}$ & $\begin{array}{l}\text { Idle mixed-grass, idle } \\
\text { shortgrass, idle } \\
\text { shrubsteppe, idle } \\
\text { tallgrass, montane } \\
\text { meadow }\end{array}$ & $\begin{array}{l}\text { Abundance was negatively correlated with percent } \\
\text { forb cover, maximum vegetation height, effective } \\
\text { vegetation height, height of emergent forb/shrub } \\
\text { cover, horizontal variation in forb and shrub height, } \\
\text { and horizontal variation in the distance to the nearest } \\
\text { forb or shrub }\end{array}$ \\
\hline Ryder 1980 & Colorado & Shortgrass pasture & $\begin{array}{l}\text { Were more abundant on heavily summer-grazed } \\
\text { areas than on lightly or moderately grazed areas; } \\
\text { nests often were situated near cowpies }\end{array}$ \\
\hline Ryder and Cobb 1969 & Colorado & Idle, shortgrass pasture & $\begin{array}{l}\text { Were present along roadsides; favored heavily } \\
\text { grazed pastures }\end{array}$ \\
\hline Sample 1989 & Wisconsin & $\begin{array}{l}\text { Burned tallgrass, } \\
\text { cropland, DNC (idle }\end{array}$ & $\begin{array}{l}\text { Were common in corn and soybeans and occurred in } \\
\text { all agricultural habitats; used areas with an average }\end{array}$ \\
\hline
\end{tabular}




\begin{tabular}{|c|c|c|c|}
\hline & & $\begin{array}{l}\text { seeded-native, idle } \\
\text { tame), idle, idle seeded- } \\
\text { native, idle tallgrass, } \\
\text { idle tallgrass/tame, idle } \\
\text { tame, tame hayland, } \\
\text { tame pasture, tame } \\
\text { savanna pasture, wet } \\
\text { meadow, wet-meadow } \\
\text { pasture }\end{array}$ & $\begin{array}{l}\text { of } 0.4 \% \text { woody cover, } 70 \% \text { herbaceous cover, } 10 \% \\
\text { litter cover, } 21 \% \text { bare ground, } 57 \mathrm{~cm} \text { maximum } \\
\text { vegetation height, and } 26 \mathrm{~cm} \text { vegetation } \\
\text { height/density; density was negatively associated } \\
\text { with percent woody cover } 0-3 \mathrm{~m} \text { tall, total percent } \\
\text { woody cover, number of dead stems } 0-3 \mathrm{~m} \text { tall, total } \\
\text { number of dead stems, maximum vegetation height, } \\
\text { percent cover of standing residual vegetation, } \\
\text { percent cover of prostrate residual vegetation, high } \\
\text { density prostrate residual vegetation (proportion of } \\
\text { quadrats with high density prostrate residual was } \\
0.1 \text { ), and plant species richness; density was } \\
\text { positively associated with low density prostrate } \\
\text { residual vegetation (proportion of quadrats with low } \\
\text { density prostrate residual was } 0.5 \text { ) and bare ground }\end{array}$ \\
\hline SWCC 1997 & Saskatchewan & Mixed-grass pasture & $\begin{array}{l}\text { Occurrence was positively associated with number } \\
\text { of contacts of narrow-leaved ( }<5 \mathrm{~mm} \text { wide) grasses } \\
\leq 10 \mathrm{~cm} \text { high and negatively associated with } \\
\text { vegetation height }\end{array}$ \\
\hline Shutler et al. 2000 & Saskatchewan & $\begin{array}{l}\text { Cropland, DNC (idle } \\
\text { seeded-native, idle } \\
\text { seeded-tame), wetland }\end{array}$ & $\begin{array}{l}\text { Were more abundant in cropland on conventional, } \\
\text { minimum-tillage, and organic farmland than in } \\
\text { DNC; presence was negatively related to number of } \\
\text { wetlands within } 2.8 \mathrm{~km}^{2} \text { of point counts and by area } \\
\text { of woody vegetation; were not detected in wetlands } \\
\text { or wetland margins }\end{array}$ \\
\hline Skinner 1974, 1975 & Missouri & $\begin{array}{l}\text { Idle tallgrass, idle tame, } \\
\text { tallgrass hayland, } \\
\text { tallgrass pasture, tame } \\
\text { hayland, tame pasture }\end{array}$ & $\begin{array}{l}\text { Occurred only in grazed plots; were more common } \\
\text { in heavily grazed areas; avoided vegetation }>30 \mathrm{~cm} \\
\text { in height; used areas of bare ground produced by } \\
\text { cattle and American bison disturbances }\end{array}$ \\
\hline Skinner et al. 1984 & Missouri & Burned tallgrass, idle & Were common only on very short (about $70 \%$ cover \\
\hline
\end{tabular}




\begin{tabular}{|c|c|c|c|}
\hline & & $\begin{array}{l}\text { tallgrass, tallgrass } \\
\text { hayland, tallgrass } \\
\text { pasture, tame pasture }\end{array}$ & $\begin{array}{l}\text { at } 1 \mathrm{~cm} \text {, about } 5 \% \text { cover at } 25 \mathrm{~cm} \text { ) grasslands, which } \\
\text { were usually heavily grazed }\end{array}$ \\
\hline Speirs and Orenstein 1967 & Ontario & $\begin{array}{l}\text { Cropland, idle, pasture, } \\
\text { tame hayland }\end{array}$ & Occurred in recently cultivated fields and bare areas \\
\hline Stewart 1975 & North Dakota & $\begin{array}{l}\text { Cropland, idle } \\
\text { shortgrass, mixed-grass } \\
\text { hayland, mixed-grass } \\
\text { pasture, tame hayland }\end{array}$ & $\begin{array}{l}\text { Were found in shortgrass, intensively grazed mixed- } \\
\text { grass, mowed mixed-grass, mowed tame haylands, } \\
\text { cropland, stubble, bare cultivated fields, and recently } \\
\text { planted fields; nested in depressions on bare or } \\
\text { sparsely vegetated ground }\end{array}$ \\
\hline Strong 1971 & Colorado & Idle, shortgrass pasture & $\begin{array}{l}\text { Ground nests were in moderately to heavily grazed } \\
\text { native grassland }\end{array}$ \\
\hline Sutter and Brigham 1998 & Saskatchewan & $\begin{array}{l}\text { Mixed-grass pasture, } \\
\text { tame pasture }\end{array}$ & $\begin{array}{l}\text { No significant difference in abundance was found } \\
\text { between mixed-grass prairie and tame stands of } \\
\text { crested wheatgrass }\end{array}$ \\
\hline Sutter et al. 2000 & Saskatchewan & Mixed-grass pasture & $\begin{array}{l}\text { Abundance in mixed-grass prairie was not } \\
\text { significantly different along roadsides than along } \\
\text { trailsides }\end{array}$ \\
\hline Wiens 1970 & Colorado & Shortgrass pasture & $\begin{array}{l}\text { Preferred heavily winter-grazed over heavily } \\
\text { summer-grazed plots; occupied sites on the heavily } \\
\text { winter-grazed plot had the following average } \\
\text { vegetation values: } 2.2 \text { contacts/ } 10 \mathrm{~cm} \text { interval } \\
\text { vertical density, } 1.1 \mathrm{~cm} \text { effective height of } \\
\text { vegetation, } 0.3 \mathrm{~cm} \text { litter depth, } 27 \% \text { litter cover, } 80 \% \\
\text { grass cover, } 2 \% \text { forb cover, } 2.5 \% \text { woody plant cover, } \\
7 \% \text { cactus cover, } 18 \% \text { bare ground cover, and } 0 \% \\
\text { rock cover; occupied sites on the heavily summer- } \\
\text { grazed plot had the following average vegetation }\end{array}$ \\
\hline
\end{tabular}




\begin{tabular}{|c|c|c|c|}
\hline & & & $\begin{array}{l}\text { characteristics: } 1.9 \text { contacts } / 10 \mathrm{~cm} \text { interval vertical } \\
\text { density, } 0.3 \mathrm{~cm} \text { effective vegetation height, } 0.2 \mathrm{~cm} \\
\text { litter depth, } 19 \% \text { litter cover, } 81 \% \text { grass cover, } 0 \% \\
\text { forb cover, } 0 \% \text { woody plant cover, } 2 \% \text { cactus cover, } \\
19 \% \text { bare ground cover, and } 0 \% \text { rock cover }\end{array}$ \\
\hline Wiens 1973 & $\begin{array}{l}\text { Colorado, } \\
\text { Montana, } \\
\text { New Mexico, } \\
\text { Oklahoma, } \\
\text { South Dakota, } \\
\text { Texas }\end{array}$ & $\begin{array}{l}\text { Idle mixed-grass, idle } \\
\text { shortgrass, mixed-grass } \\
\text { pasture, semidesert } \\
\text { shrubsteppe pasture, } \\
\text { shortgrass pasture, } \\
\text { tallgrass pasture }\end{array}$ & $\begin{array}{l}\text { Preferred sites with short grass and emergent } \\
\text { vegetation, and moderate heterogeneity; at the } \\
\text { Colorado site, used areas where forbs and woody } \\
\text { vegetation were sparse, and where vertical aspect of } \\
\text { vegetation was not very well-developed; mean } \\
\text { vegetation values for used areas in heavy winter } \\
\text { grazed areas were as follows: } 82 \% \text { grass cover, } 10 \% \\
\text { forb, } 3 \% \text { woody, } 1 \% \text { cactus, } 16 \% \text { bare ground, and } \\
0 \% \text { rock; stem density in individuals } / \mathrm{m}^{2}: 264 \text { forb, } \\
45 \text { woody, and } 113 \text { cactus; } 100 \% \text { open sky at ground } \\
\text { level, } 0.31 \text { cm litter depth, } 23 \% \text { litter cover; } 1.5 \\
\text { heterogeneity index (based on maximum and } \\
\text { minimum values for vertical vegetation density, and } \\
\text { served as a measure of both vertical and horizontal } \\
\text { patchiness), } 8 \mathrm{~cm} \text { emergent vegetation height, } 2.4 \\
\text { vertical density; } 98 \% \text { density }<10 \mathrm{~cm} \text {, and } 0.7 \mathrm{~cm} \\
\text { effective height }\end{array}$ \\
\hline With and Webb 1993 & Colorado & Shortgrass pasture & $\begin{array}{l}\text { Nests experienced complete solar exposure at } \\
\text { midday and } 45 \% \text { total exposure per day; most nests } \\
\text { had a northeast orientation relative to vegetation or } \\
\text { the structure near the nest; nested near cowpies }\end{array}$ \\
\hline
\end{tabular}

* In an effort to standardize terminology among studies, various descriptors were used to denote the management or type of habitat. "Idle" used as a modifier (e.g., idle tallgrass) denotes undisturbed or unmanaged (e.g., not burned, mowed, or grazed) areas. "Idle" by itself denotes unmanaged areas in which the plant species were not mentioned. Examples of "idle" habitats include weedy or fallow areas (e.g., oldfields), fencerows, grassed waterways, terraces, ditches, and road rights-of-way. "Tame" denotes introduced plant species (e.g., smooth brome [Bromus inermis]) that are not native to North American prairies. "Hayland" refers to any habitat that was mowed, regardless of whether the resulting cut vegetation was removed. "Burned" includes habitats that were burned intentionally or accidentally or those burned by natural forces (e.g., lightning). In situations where there are two or more descriptors (e.g., idle tame hayland), the first 
descriptor modifies the following descriptors. For example, idle tame hayland is habitat that is usually mowed annually but happened to be undisturbed during the year of the study. 


\section{LITERATURE CITED}

Anstey, D. A., S. K. Davis, D. C. Duncan, and M. Skeel. 1995. Distribution and habitat requirements of eight grassland songbird species in southern Saskatchewan.

Saskatchewan Wetland Conservation Corporation, Regina, Saskatchewan. 11 pages.

Arnold, T. W., and K. F. Higgins. 1986. Effects of shrub coverages on birds of North Dakota mixed-grass prairies. Canadian Field-Naturalist 100:10-14.

Beason, R. C. 1970. The annual cycle of the Prairie Horned Lark in west central Illinois. M.S. thesis. Western Illinois University, Macomb, Illinois. 160 pages.

Beason, R. C. 1995. Horned Lark (Eremophila alpestris). In A. Poole and F. Gill, editors. The birds of North America, No. 195. The Academy of Natural Sciences, Philadelphia, Pennsylvania; The American Ornithologists’ Union, Washington, D.C.

Beason, R. C., and E. C. Franks. 1974. Breeding behavior of the Horned Lark. Auk 91:65-74.

Bent, A. C. 1942. Life histories of North American flycatchers, larks, swallows, and their allies. Dover Publications, Inc., New York, New York. 555 pages.

Best, L. B., H. Campa, III, K. E. Kemp, R. J. Robel, M. R. Ryan, J. A. Savidge, H. P. Weeks, Jr., and S. R. Winterstein. 1997. Bird abundance and nesting in CRP fields and cropland in the Midwest: a regional approach. Wildlife Society Bulletin 25:864-877.

Best, L. B., and B. J. Hill. 1983. Fencerows are for the birds. Iowa Bird Life 53:16-21.

Best, L. B., R. C. Whitmore, and G. M. Booth. 1990. Use of cornfields by birds during the breeding season: the importance of edge habitat. American Midland Naturalist 123:8499.

Bock, C. E., J. H. Bock, and B. C. Bennett. 1995. The avifauna of remnant tallgrass prairie near Boulder, Colorado. Prairie Naturalist 27:147-157.

Bock, C. E., J. H. Bock, and B. C. Bennett. 1999. Songbird abundance in grasslands at a suburban interface on the Colorado High Plains. Pages 131-136 in P. D. Vickery and J. R. Herkert, editors. Ecology and conservation of grassland birds of the Western Hemisphere. Studies in Avian Biology 19.

Boyd, R. L. 1976. Behavioral biology and energy expenditure in a Horned Lark population. Ph.D. dissertation. Colorado State University, Fort Collins, Colorado. 194 pages.

Bryan, G. G., and L. B. Best. 1991. Bird abundance and species richness in grassed waterways in Iowa rowcrop fields. American Midland Naturalist 126:90-102.

Camp, M., and L. B. Best. 1993. Bird abundance and species richness in roadsides adjacent to Iowa rowcrop fields. Wildlife Society Bulletin 21:315-325. 
Cassel, J. F. 1952. Breeding bird populations at various altitudes in north central Colorado. Ph.D. dissertation. University of Colorado, Boulder, Colorado. 147 pages.

Castrale, J. S. 1985. Responses of wildlife to various tillage conditions. Transactions of the North American Wildlife and Natural Resources Conference 50:142-149.

Clapp, R. B., M. K. Klimkiewicz, and A. G. Futcher. Longevity records of North American birds: columbidae through paridae. Journal of Field Ornithology 54:123-137.

Clark, W. D., and J. R. Karr. 1979. Effects of highways on Red-winged Blackbird and Horned Lark populations. Wilson Bulletin 91:43-145.

Creighton, P. D. 1974. Habitat exploitation by an avian ground-foraging guild. Ph.D. dissertation. Colorado State University, Fort Collins, Colorado. 154 pages.

Dale, B. C. 1983. Habitat relationships of seven species of passerine birds at Last Mountain Lake, Saskatchewan. M.S. thesis. University of Regina, Regina, Saskatchewan. 119 pages.

Dale, B. C. 1984. Birds of grazed and ungrazed grasslands in Saskatchewan. Blue Jay 42:102105.

Dale, B. C. 1992. North American Waterfowl Management Plan implementation program related to non-game studies within the Prairie Habitat Joint Venture area, Annual Report 1991-1992. Unpublished report. Canadian Wildlife Service, Saskatoon, Saskatchewan. 66 pages.

Dale, B. C. 1993. 1992 Saskatchewan non-game bird evaluation of North American Waterfowl Management Plan: DNC and short grass cover-1992. Unpublished report. Canadian Wildlife Service, Edmonton, Alberta; Saskatchewan Wetland Conservation Corporation, Regina, Saskatchewan. 23 pages.

Dale, B. C., P. A. Martin, and P. S. Taylor. 1997. Effects of hay management on grassland songbirds in Saskatchewan. Wildlife Society Bulletin 25:616-626.

Davis, S. K., and D. C. Duncan. 1999. Grassland songbird abundance in native and crested wheatgrass pastures of southern Saskatchewan. Pages 211-218 in J. Herkert and P. Vickery, editors. Ecology and conservation of grassland birds of the Western Hemisphere. Studies in Avian Biology 19.

Davis, S. K., D. C. Duncan, D. A. Anstey, and M. Skeel. 1997. Habitat selection of grassland songbirds in southern Saskatchewan. Unpublished report to the Saskatchewan Wetland Conservation Corporation, Regina, Saskatchewan. 31 pages. 
DeWeese, L. R., C. Lowell, L. A. S. McEwen, and R. D. Deblinger. 1983. Effects on birds of fenthion aerial application for mosquito control. Journal of Economic Entomology 76:906-911.

DuBois, A. D. 1935. Nests of Horned Larks and longspurs on a Montana prairie. Condor 37:56-72.

Ducey, J., and L. Miller. 1980. Birds of an agricultural community. Nebraska Bird Review 48:58-68.

Faanes, C. A. 1981. Birds of the St. Croix River Valley: Minnesota and Wisconsin. U.S. Fish and Wildlife Service, Washington, D.C. North American Fauna 73. 196 pages.

Faanes, C. A. 1983. Breeding birds of wooded draws in western North Dakota. Prairie Naturalist 15:173-187.

Faanes, C. A., and G. R. Lingle. 1995. Breeding birds of the Platte River Valley of Nebraska. Jamestown, ND: Northern Prairie Wildlife Research Center home page. http://www.npwrc.usgs.gov/resource/distr/birds/platte/platte.htm (Version 02SEP99).

Friedmann, H. 1963. Host relations of the parasitic cowbirds. U.S. National Museum Bulletin 233:1-276.

Friedmann, H., L. F. Kiff, and S. I. Rothstein. 1977. A further contribution to knowledge of the host relations of the parasitic cowbirds. Smithsonian Contributions to Zoology 235:1-75.

George, J. L. 1952. The birds on a southern Michigan farm. Ph.D. dissertation. University of Michigan, Ann Arbor, Michigan. 413 pages.

George, T. L., L. C. McEwen, and B. E. Peterson. 1995. Effects of grasshopper control programs on rangeland breeding bird populations. Journal of Range Management 48:336-342.

Giezentanner, J. B. 1970a. Avian distribution and population fluctuations on the shortgrass prairie of north central Colorado. M.S. thesis. Colorado State University, Fort Collins, Colorado. 113 pages.

Giezentanner, J. B. 1970b. Avian distribution and population fluctuations on the shortgrass prairie of north central Colorado. U.S. International Biological Program, Grassland Biome Technical Report 62. Colorado State University, Fort Collins, Colorado. 112 pages.

Giezentanner, J. B., and R. A. Ryder. 1969. Avian distribution and population fluctuations at the Pawnee site. U.S. International Biological Program, Grassland Biome Technical Report 28. Colorado State University, Fort Collins, Colorado. 29 pages. 
Graber, R. R., and J. W. Graber. 1963. A comparative study of bird populations in Illinois, 1906-1909 and 1956-1958. Illinois Natural History Survey Bulletin 28:383-528.

Greer, R. D. 1988. Effects of habitat structure and productivity on grassland birds. Ph.D. dissertation. University of Wyoming, Laramie, Wyoming. 129 pages.

Gremaud, G. K. 1983. Factors influencing nongame bird use of rowcrop fields. M.S. thesis. Iowa State University, Ames, Iowa. 56 pages.

Griebel, R. L., S. L. Winter, and A. A. Steuter. 1998. Grassland birds and habitat structure in sandhills prairie management using cattle or bison plus fire. Great Plains Research 8:255-268.

Hartley, M. J. 1994a. Passerine abundance and productivity indices in grasslands managed for waterfowl nesting cover. Transactions of the North American Wildlife and Natural Resources Conference 59:322-327.

Hartley, M. J. 1994b. Passerine abundance and productivity indices in grasslands managed for waterfowl nesting cover in Saskatchewan, Canada. M.S. thesis. Louisiana State University, Baton Rouge, Louisiana. 42 pages.

Herkert, J. R. 1991. Study suggests increases in restored prairie fragments to conserve breeding bird communities. Restoration and Management Notes 9:107.

Hill, R. A. 1976. Host-parasite relationships of the Brown-headed Cowbird in a prairie habitat of west-central Kansas. Wilson Bulletin 88:555-565.

Huber, G. E., and A. A. Steuter. 1984. Vegetation profile and grassland bird response to spring burning. Prairie Naturalist 16:55-61.

Janssen, R. B. 1987. Birds in Minnesota. University of Minnesota Press, Minneapolis, Minnesota. 352 pages.

Johnsgard, P. A. 1980. A preliminary list of the birds of Nebraska and adjacent Plains states. University of Nebraska, Lincoln, Nebraska. 156 pages.

Johnson, D. H., and L. D. Igl. 1995. Contributions of the Conservation Reserve Program to populations of breeding birds in North Dakota. Wilson Bulletin 107:709-718.

Johnson, D. H., and M. D. Schwartz. 1993a. The Conservation Reserve Program and grassland birds. Conservation Biology 7:934-937.

Johnson, D. H., and M. D. Schwartz. 1993b. The Conservation Reserve Program: habitat for grassland birds. Great Plains Research 3:273-295. 
Jones, R. E. 1994. Non-waterfowl evaluation of Manitoba’s North American Waterfowl Management Program. Unpublished report. Wildlife Branch, Manitoba Department of Natural Resources, Winnipeg, Manitoba. 15 pages.

Kahl, R. B., T. S. Baskett, J. A. Ellis, and J. N. Burroughs. 1985. Characteristics of summer habitats of selected nongame birds in Missouri. Research Bulletin 1056. University of Missouri, Columbia, Missouri. 155 pages.

Kantrud, H. A. 1981. Grazing intensity effects on the breeding avifauna of North Dakota native grasslands. Canadian Field-Naturalist 95:404-417.

Kantrud, H. A., and R. L. Kologiski. 1982. Effects of soils and grazing on breeding birds of uncultivated upland grasslands of the northern Great Plains. U.S. Fish and Wildlife Service, Wildlife Research Report 15. 33 pages.

Karasiuk, D., H. Vriend, J. G. Stelfox, and J. R. McGillis. 1977. Avifauna: Study results from Suffield, 1976. Pages 33-44 in J. G. Stelfox, editor. Effects of livestock grazing on mixed prairie range and wildlife within PFRA pastures, Suffield Military Reserve.

Kent, T. H., and J. J. Dinsmore. 1996. Birds in Iowa. Published by the authors, Iowa City and Ames, Iowa. 391 pages.

Kerley, L. L., and S. H. Anderson. 1995. Songbird responses to sagebrush removal in a high elevation sagebrush steppe ecosystem. Prairie Naturalist 27:129-146.

King, J. W., and J. A. Savidge. 1995. Effects of the Conservation Reserve Program on wildlife in southeast Nebraska. Wildlife Society Bulletin 23:377-385.

Knapton, R. W., and P. Mineau. 1995. Effects of granular formulations of terbufos and fonofos applied to cornfields on mortality and reproductive success of songbirds. Ecotoxicology 4:138-153.

Koford, R. R., B. S. Bowen, J. T. Lokemoen, and A. D. Kruse. 2000. Cowbird parasitism in grassland and cropland in the northern Great Plains. Pages 229-235 in J. N. M. Smith, T. L. Cook, S. I. Rothstein, S. K. Robinson, and S. G. Sealy, editors. Ecology and management of cowbirds and their hosts. University of Texas Press, Austin, Texas.

Maher, W. J. 1973. Matador Project: Birds I. Population dynamics. Canadian Committee for the International Biological Programme, Matador Project, Technical Report 34. University of Saskatchewan, Saskatoon, Saskatchewan. 56 pages.

Maher, W. J. 1974. Matador Project: Birds II. Avifauna of the Matador area. Canadian Committee for the International Biological Programme, Matador Project, Technical Report 58. University of Saskatchewan, Saskatoon, Saskatchewan. 31 pages. 
Martin, P. A., and D. J. Forsyth. 2003. Occurrence and productivity of songbirds in prairie farmland under conventional versus minimum tillage regimes. Agriculture Ecosystems and Environment 96:107-117.

McEwen, L. C., and J. O. Ells. 1975. Field ecology investigations of the effects of selected pesticides on wildlife populations. U.S. International Biological Program, Grassland Biome Technical Report 289. Colorado State University, Fort Collins, Colorado. 36 pages.

McEwen, L. C., C. E. Knittle, and M. L. Richmond. 1972. Wildlife effects from grasshopper insecticides sprayed on short-grass range. Journal of Range Management 25:188-194.

McEwen, L. C., L. R. DeWeese, and P. Schladweiler. 1986. Bird predation on cutworms (Lepidoptera: Noctuidae) in wheat fields and chlorpyrifos effects on brain cholinesterase activity. Environmental Entomology 15:147-151.

McMaster, D. G. 1998. 1998 non-game evaluation of the Permanent Cover Program. Alberta North American Waterfowl Management Plan and Saskatchewan Wetland Conservation Corporation, Regina, Saskatchewan. 4 pages.

McMaster, D. G., and S. K. Davis. 1998. Non-game evaluation of the Permanent Cover Program. Unpublished report. Saskatchewan Wetland Conservation Corporation, Regina, Saskatchewan. $75+$ pages.

Messmer, T. A. 1990. Influence of grazing treatments on nongame birds and vegetation structure in south central North Dakota. Ph.D. dissertation. North Dakota State University, Fargo, North Dakota. 164 pages.

National Geographic Society. 1999. Field guide to the birds of North America, third edition. National Geographic Society, Washington, D.C. 480 pages.

Owens, R. A., and M. T. Myres. 1973. Effects of agriculture upon populations of native passerine birds of an Alberta fescue grassland. Canadian Journal of Zoology 51:697-713.

Patterson, M. P. 1994. Bird species abundance, composition, and vegetation characteristics, and bird productivity in Conservation Reserve Program land in central Iowa. M.S. thesis. Iowa State University, Ames, Iowa. 54 pages.

Patterson, M. P., and L. B. Best. 1996. Bird abundance and nesting success in Iowa CRP fields: the importance of vegetation structure and composition. American Midland Naturalist 135:153-167.

Peabody, P. B. 1899. Clay-colored Sparrow. Oologist 16:177-180. 
Porter, D. K., and R. A. Ryder. 1974. Avian density and productivity studies and analyses on the Pawnee Site in 1972. U.S. International Biological Program, Grassland Biome Technical Report 252. Colorado State University, Fort Collins, Colorado. 77 pages.

Prescott, D. R. C. 1997. Avian communities and NAWMP habitat priorities in the northern prairie biome of Alberta. NAWMP-029. Land Stewardship Centre of Canada, St. Albert, Alberta. 41 pages.

Prescott, D. R. C., R. Arbuckle, B. Goddard, and A. J. Murphy. 1993. Methods for the monitoring and assessment of avian communities on NAWMP landscapes in Alberta, and 1993 results. NAWMP-007. Alberta NAWMP Centre, Edmonton, Alberta. 48 pages.

Prescott, D. R. C., and A. J. Murphy. 1996. Habitat associations of grassland birds on native and tame pastures of the aspen parkland in Alberta. NAWMP-021. Alberta NAWMP Centre, Edmonton, Alberta. 36 pages.

Prescott, D. R. C., and A. J. Murphy. 1999. Bird populations in seeded nesting cover on North American Waterfowl Management Plan properties in the aspen parkland of Alberta. Pages 203-210 in P. D. Vickery and J. R. Herkert, editors. Ecology and conservation of grassland birds of the Western Hemisphere. Studies in Avian Biology 19.

Prescott, D. R. C., and G. M. Wagner. 1996. Avian responses to implementation of a complementary/rotational grazing system by the North American Waterfowl Management Plan in southern Alberta: the Medicine Wheel Project. NAWMP-018. Alberta NAWMP Centre, Edmonton, Alberta. 24 pages.

Pylypec, B. 1991. Impacts of fire on bird populations in a fescue prairie. Canadian FieldNaturalist 105:346-349.

Renken, R. B. 1983. Breeding bird communities and bird-habitat associations on North Dakota waterfowl production areas of three habitat types. M.S. thesis. Iowa State University, Ames, Iowa. 90 pages.

Renken, R. B., and J. J. Dinsmore. 1987. Nongame bird communities on managed grasslands in North Dakota. Canadian Field-Naturalist 101:551-557.

Robbins, S. D., Jr. 1949. The 1948 nesting season. Passenger Pigeon 11:21-28.

Rotenberry, J. T., and J. A. Wiens. 1980. Habitat structure, patchiness, and avian communities in North American steppe vegetation: a multivariate analysis. Ecology 61:1228-1250.

Ryder, R. A. 1980. Effects of grazing on bird habitats. Pages 51-66 in R. M. DeGraff and N. G. Tilghman, editors. Management of western forests and grasslands for nongame birds. U.S.D.A. Forest Service, General Technical Report INT-86. 
Ryder, R. A., and D. A. Cobb. 1969. Birds of the Pawnee National Grasslands in northern Colorado. Journal of the Colorado-Wyoming Academy of Science 6:5.

Ryder, R. A. 1972. Avian population studies on the Pawnee Site, 1968-1971. U. S. International Biological Program, Grassland Biome Technical Report 171. Colorado State University, Fort Collins, Colorado. 62 pages.

Salt, W. R., and J. R. Salt. 1976. The birds of Alberta. Hurtig Publishers, Edmonton, Alberta. 498 pages.

Sample, D. W. 1989. Grassland birds in southern Wisconsin: habitat preference, population trends, and response to land use changes. M.S. thesis. University of Wisconsin, Madison, Wisconsin. 588 pages.

Saskatchewan Wetland Conservation Corporation (SWCC). 1997. Grassland bird conservation through Saskatchewan's native prairie stewardship program. Saskatchewan Wetland Conservation Corporation, Regina, Saskatchewan. 25 pages.

Shaffer, J. A., C. M. Goldade, M. F. Dinkins, D. H. Johnson, L. D. Igl, and B. R. Euliss. 2003. Brown-headed Cowbirds in grasslands: their habitats, hosts, and response to management. Prairie Naturalist 35:146-186.

Shutler, D., A. Mullie, and R. G. Clark. 2000. Bird communities of prairie uplands and wetlands in relation to farming practices in Saskatchewan. Conservation Biology 14:1441-1451.

Skinner, R. M. 1974. Grassland use patterns and prairie bird populations in Missouri. M.A. thesis. University of Missouri, Columbia, Missouri. 53 pages.

Skinner, R. M. 1975. Grassland use patterns and prairie bird populations in Missouri. Pages 171-180 in M. K. Wali, editor. Prairie: a multiple view. University of North Dakota Press, Grand Forks, North Dakota.

Skinner, R. M., T. S. Baskett, and M. D. Blendon. 1984. Bird habitat on Missouri prairies. Terrestrial Series 14. Missouri Department of Conservation, Jefferson City, Missouri. 37 pages.

Speirs, J. M., and R. Orenstein. 1967. Bird populations in fields of Ontario County, 1965. Canadian Field-Naturalist 81:175-183.

Stallman, H. R., and L. B. Best. 1996. Bird use of an experimental strip intercropping system in northeast Iowa. Journal of Wildlife Management 60:354-362.

Stewart, R. E. 1975. Breeding birds of North Dakota. Tri-College Center for Environmental Studies, Fargo, North Dakota. 295 pages. 
Strong, M. A. 1971. Avian productivity on the shortgrass prairie of northcentral Colorado. M.S. thesis. Colorado State University, Fort Collins, Colorado. 70 pages.

Sutter, G. C., and R. M. Brigham. 1998. Avifaunal and habitat changes resulting from conversion of native prairie to crested wheat grass: patterns at songbird community and species levels. Canadian Journal of Zoology 76:869-875.

Sutter, G. C., S. K. Davis, and D. C. Duncan. 2000. Grassland songbird abundance along roads and trails in southern Saskatchewan. Journal of Field Ornithology 71:110-116.

Vickery, P. D. 1993. Habitat selection of grassland birds in Maine. Ph.D. dissertation. University of Maine, Orono, Maine. 124 pages.

Wiens, J. A. 1970. Avian populations and patterns of habitat occupancy at the Pawnee site, 1968-1969. U.S. International Biological Program, Grassland Biome Technical Report 63. Colorado State University, Fort Collins, Colorado. 57 pages.

Wiens, J. A. 1971. Avian ecology and distribution in the comprehensive network, 1970. U.S. International Biological Program, Grassland Biome Technical Report 77. Colorado State University, Fort Collins, Colorado. 49 pages.

Wiens, J. A. 1973. Pattern and process in grassland bird communities. Ecological Monographs 43:237-270.

With, K. A., and D. R. Webb. 1993. Microclimate of ground nests: the relative importance of radiative cover and wind breaks for three grassland species. Condor 95:401-413. 